\title{
血栓を防ぐ（後編）：脳梗塞の抗凝固療法
}

平野照之*

\section{Role of anticoagulation for ischemic stroke patients}

Teruyuki HIRANO

要約 : 脳梗塞の抗凝固療法には, 急性期治療薬掞よび再発予防薬としての位 置付けがある。臨床現場では, 脳梗塞急性期に未分画へパリンの持続静注を 用いることが多いが, そのエビデンスはそしい, 一方, 非弁膜症性心房細動 を有する脳梗塞の再発予防に㧍ける経口抗凝固療法の意義は確立している. 直接阻害型経口抗凝固薬 (direct oral anticoagulant, DOAC) またはワルファ リンから患者プロファイルに適したものを選んで使用する。

Key words: anticoagulation, cardioembolic stroke, atrial fibrillation, direct oral anticoagulants, warfarin

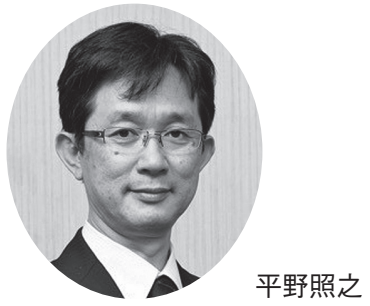

1988年

熊本大学医学部卒業 同第一内科入局

1991年

国立循環器病センターレジ

テント内科脳血管部門 1996年

メルボルン大学 National Stroke Research Institute留学 1999年

熊本大学神経内科 2012年

医員・助手・講師

大分大学第三内科・神経内科 准教授

2014年

杏林大学脳卒中医学 教授

\section{1. はじめに}

脳梗塞に対する抗凝固療法の応用の歴史は長く, ヘパリンが使用されはじめたのは 1950 年代にさか のぼる ${ }^{1)}$ ，血栓溶解療法のように既に出来上がった 血栓を溶解するまでの効果はないが，抗凝固療法に よって血栓形成の進展を抑え，遠位への血栓塞栓を 減らすことで, 症状の進行阻止, 病巣拡大の阻止, 患者転帰の改善が期待されると考えられてきた。し かし, 今日までに行われた多数のランダム化比較試 験とそのメ夕解析の結果によると, 肺塞栓や深部静 脈血栓症などの合併症の予防効果はみられるもの の, 脳梗塞の転帰改善という本来の目的に対する有 効性は証明されていない.

一方，脳梗塞慢性期には再発予防を目的として抗 凝固療法が行われる。再発予防のための抗血栓薬の 開始時期は, 脳浮腫などの脳梗塞急性期の病態が落 ち着いた時点，すなわち再発リスクの高い時期であ

\footnotetext{
*責任者連絡先：

杏林大学医学部脳卒中医学

干 181-8611 三鷹市新川 6-20-2

Tel: 0422-47-5511, Fax: 0422-76-0258

E-mail: terry@ks.kyorin-u.ac.jp
}

る。できるだけ早く導入し，再発予防下に積極的に リハビリテーションを行う体制に移行する。抗血栓 薬として抗凝固薬と抗血小板薬のどちらを用いるか は，脳梗塞の病型，すなわち心原性脳塞栓症か非心 原性脳梗塞(アテローム血栓性脳梗塞, ラクナ梗塞, その他)によって決定する。しかし，どのような臨床 病型であっても心房細動の合併が判明すれば，一律 に抗凝固療法が選択される。1940年代に開発された ワルファリンは, 長らく経口で使用可能な唯一の抗 凝固薬であった。近年, ワルファリン以外に新規の 経口抗凝固薬が加わり, 治療の選択肢が増えている.

\section{2. 脳梗塞に用いる抗凝固薬}

現在，臨床で用いることのできる薬剤を図 1 に示 す。注射薬には，未分画へパリン(主として第 Xa 因子を抑制，アンチトロンビン III 依存性)，低分子 ヘパリン(第Xa 因子とトロンビンを $1: 1$ の比率で 抑制, アンチトロンビン III 依存性), アルガトロバン （選択的トロンビン阻害薬，アンチトロンビン III 非 依存性)がある。アルガトロバンは発症 48 時間以内 のアテローム血栓性脳梗塞に保険適応がある。

内服薬にはワルファリン，ダビガトラン，リバー 


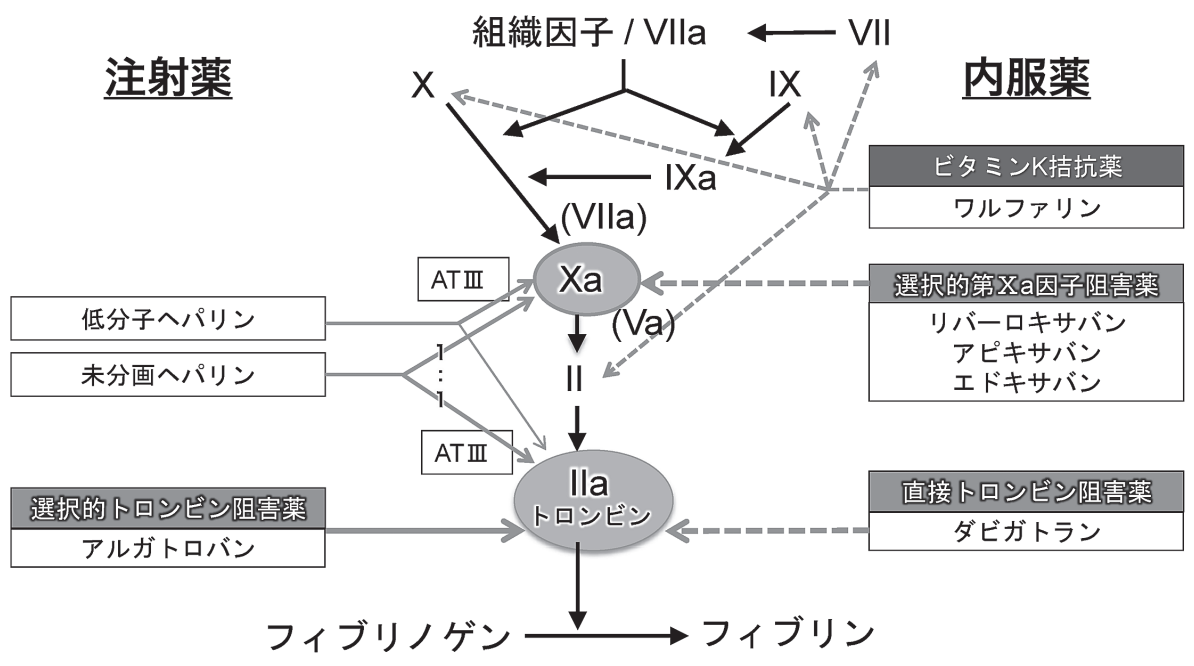

図 1 脳梗塞に用いる抗凝固薬の凝固カスケードにおける作用部位

ロキサバン，アピキサバン，エドキサバンの 5 剂が ある。ワルファリンはビタミン $\mathrm{K}$ 阻害薬であり, 凝 固第 VII，IX，X，II 因子の産生を抑制することで抗 凝固活性を示す。ダビガトランは直接トロンビン阻 害薬，リバーロキサバン，アピキサバン，エドキサ バンは第 Xa 因子の阻害薬である。いずれも凝固因 子の活性部位を直接阻害することで抗凝固活性を発 揮するため, 直接型経口抗凝固薬 (direct oral anticoagulant, DOAC) と総称される.

\section{3. 脳梗塞急性期の抗凝固療法}

急性期の抗凝固療法の目的は, 心原性脳塞栓症の 早期再発防止, 心腔内血栓, 脳動脈解離, 静脈洞血 栓症の治療などである. 残念ながら脳梗塞の転帰改 善効果は示されていないが, 患者の病態に応じて広 く用いられている.

\section{1）注射薬}

脳梗塞急性期には，意識障害，嚥下機能障害など を伴うことが多いため, 経口抗凝固薬の使用は困難 なことも少なくない。したがって静注あるいは皮下 注製片を選択することになり，日本ではへパリン静 注あるいはアルガトロバン静注が用いられる。へパ リンはウシやブタ由来のグリコサミノグリカンであ り，種々の分子量のものが混在しており，未分画へ パリン (unfractionated heparin: UFH) と呼ばれる.アン チトロンビン III と結合してトロンビンを阻害する
が，他の凝固因子の阻害作用，血小板機能の阻害作 用も有しており，効果に個人差が大きいため通常は 活性化部分トロンボプラスチン時間 (aPTT) をモニ ターしながら用いる。U UFH を酵素あるいは化学的 処理で低分子化した低分子へパリン (low molecular weight heparin: LMWH)やヘパリノイド(ヘパリン類 似物質)は，安定した抗凝固作用と出血性合併症の 軽減が期待され，様々な臨床試験が行われた（表1).

a. 未分画へパリン

The International Stroke Trial $(\text { IST })^{2}$ は，急性期抗血 栓療法の有効性安全性を明らかにする目的で 20,000 例近い症例をエントリーした大規模臨床試験であ る。発症 48 時間以内に, UFH 皮下注 $(5,000$ 単位ま たは 12,500 単位, 1 日 2 回)の有無で 3 通り, アス ピリン 1 日 $300 \mathrm{mg}$ 服用の有無で 2 通りに振り分け, 6 群での効果が検証された。その結果, UFH 使用群 は非使用群より, 有意差はないものの 14 日以内の 死亡が少なく, 6 カ月目の死亡または要介助では差 がなかった。14 日以内の再発は有意に少なかった が, 出血性脳卒中は逆に増加した。

b. 低分子ヘパリン

The Trial of ORG 10172 in Acute Stroke Treatment $(\mathrm{TOAST})^{3)}$ は, LMWH (Danaparoid)の急性期脳梗塞 患者に対する有効性安全性を評価した二重盲検試験 である。発症 24 時間以内に Danaparoid またはプラ セボを静注し，抗 Xa 因子活性によって用量調整し つつ 7 日間静注が行われた。7日後の転帰良好例は 
表 1 急性期脳梗塞に対する抗凝固療法の主な比較試験

\begin{tabular}{|c|c|c|c|c|c|c|c|c|c|c|c|}
\hline & \multicolumn{2}{|c|}{$\begin{array}{c}\text { IST } \\
(1997)\end{array}$} & \multicolumn{2}{|c|}{$\begin{array}{l}\text { TOAST } \\
(1998)\end{array}$} & \multicolumn{2}{|c|}{$\begin{array}{l}\text { HAEST } \\
(2000)\end{array}$} & \multicolumn{3}{|c|}{$\begin{array}{l}\text { TAIST } \\
(2001)\end{array}$} & \multicolumn{2}{|c|}{$\begin{array}{l}\text { FISS-tris } \\
(2007)\end{array}$} \\
\hline 対象 & \multicolumn{2}{|c|}{$\begin{array}{l}\text { 脳梗塞 } \\
<48 \mathrm{hr}\end{array}$} & \multicolumn{2}{|c|}{$\begin{array}{l}\text { 脳梗塞 } \\
<24 \mathrm{hr}\end{array}$} & \multicolumn{2}{|c|}{$\begin{array}{c}\text { AF 脳梗塞 } \\
<30 \mathrm{hr}\end{array}$} & \multicolumn{3}{|c|}{$\begin{array}{l}\text { 脳梗塞 } \\
<48 \mathrm{hr}\end{array}$} & \multicolumn{2}{|c|}{$\begin{array}{l}\text { 主幹動脈病変 } \\
\text { 脳梗塞 }<48 \mathrm{hr}\end{array}$} \\
\hline $\begin{array}{c}\text { 治療 } \\
\mathrm{n}\end{array}$ & $\begin{array}{l}\text { UFH } \\
9,717\end{array}$ & $\begin{array}{c}\text { No } \\
9,718\end{array}$ & $\begin{array}{l}\text { LMWH } \\
641\end{array}$ & $\begin{array}{c}\text { Placebo } \\
634\end{array}$ & $\begin{array}{l}\text { LMWH } \\
224\end{array}$ & $\begin{array}{c}\text { ASA } \\
225\end{array}$ & $\begin{array}{c}\text { LMWH } \\
\text { 高用量 } \\
487\end{array}$ & $\begin{array}{c}\text { LMWH } \\
\text { 中用量 } \\
508\end{array}$ & $\begin{array}{c}\text { ASA } \\
491\end{array}$ & $\begin{array}{l}\text { LMWH } \\
180\end{array}$ & $\begin{array}{c}\text { ASA } \\
173\end{array}$ \\
\hline $\begin{array}{l}\text { 投与 } \\
\text { 期間 }\end{array}$ & \multicolumn{2}{|c|}{14 日間 } & \multicolumn{2}{|c|}{7 日間 } & \multicolumn{2}{|c|}{14 日間 } & \multicolumn{3}{|c|}{10 日間 } & \multicolumn{2}{|c|}{10 日間 } \\
\hline \multirow[t]{6}{*}{$\begin{array}{l}\text { 主要評 } \\
\text { 価項目 }\end{array}$} & \multicolumn{2}{|c|}{14 日以内死亡 } & \multicolumn{2}{|c|}{3 力月転帰良好 } & \multicolumn{2}{|c|}{$\begin{array}{c}14 \text { 日以内 } \\
\text { 脳梗塞再発 }\end{array}$} & \multicolumn{3}{|c|}{$\begin{array}{l}6 \text { 力月後 } \\
\mathrm{mRS} 0-2\end{array}$} & \multicolumn{2}{|c|}{$\begin{array}{c}6 \text { 力月後 } \\
\mathrm{BI} \geq 85\end{array}$} \\
\hline & $9.0 \%$ & $9.3 \%$ & $75.2 \%$ & $73.7 \%$ & $8.5 \%$ & $7.5 \%$ & $41.5 \%$ & $42.4 \%$ & $42.5 \%$ & $73 \%$ & $69 \%$ \\
\hline & \multicolumn{2}{|c|}{ n.s. } & \multicolumn{2}{|c|}{ n.s. } & \multicolumn{2}{|c|}{ n.s. } & \multicolumn{3}{|c|}{ n.s. } & \multicolumn{2}{|c|}{ n.s. } \\
\hline & \multicolumn{2}{|c|}{$\begin{array}{c}6 \text { 力月後 } \\
\text { 死亡／要介助 }\end{array}$} & \multicolumn{2}{|c|}{7 日後の転帰良好 } & & & & & & \multicolumn{2}{|c|}{$\begin{array}{l}6 \text { 力月後 } \\
\mathrm{mRS} 0-1\end{array}$} \\
\hline & $62.9 \%$ & $62.9 \%$ & $59.2 \%$ & $54.3 \%$ & & & & & & $54 \%$ & $44 \%$ \\
\hline & \multicolumn{2}{|c|}{ n.s. } & \multicolumn{2}{|c|}{$\mathrm{p}=0.07$} & & & & & & \multicolumn{2}{|c|}{$\begin{array}{c}\text { OR } 1.55 \\
{[1.02-2.35]}\end{array}$} \\
\hline \multirow[t]{6}{*}{$\begin{array}{l}\text { 副次評 } \\
\text { 価項目 }\end{array}$} & \multicolumn{2}{|c|}{$\begin{array}{c}14 \text { 日以内 } \\
\text { 脳梗塞再発 }\end{array}$} & \multicolumn{2}{|c|}{$\begin{array}{c}10 \text { 日以内 } \\
\text { 脳梗塞再発 }\end{array}$} & $\begin{array}{l}6 \text { 大 } \\
\text { 生沙 }\end{array}$ & $\begin{array}{l}\text { 後 } \\
\text { 立 }\end{array}$ & & $\begin{array}{l}15 \text { 日以内 } \\
\text { 临梗塞再垔 }\end{array}$ & & $\begin{array}{l}10 \\
\text { 症壮 }\end{array}$ & \\
\hline & $2.9 \%$ & $3.8 \%$ & $1.7 \%$ & $1.8 \%$ & $22.8 \%$ & $21.3 \%$ & $3.3 \%$ & $4.7 \%$ & $3.1 \%$ & $6 \%$ & $5 \%$ \\
\hline & & & & & & & & n.s. & & & \\
\hline & & $\begin{array}{l}\text { 人内 } \\
\text { 血 }\end{array}$ & $\begin{array}{l}10 \\
\text { 脳 }\end{array}$ & $\begin{array}{l}\text { 以内 } \\
\text { 血 }\end{array}$ & $\begin{array}{c}14 \mid \\
\text { 頭蓋 }\end{array}$ & $\begin{array}{l}\text { 背血 } \\
\text { 血 }\end{array}$ & & $\begin{array}{l}15 \text { 日以内 } \\
\text { 脳出血 }\end{array}$ & & 6 力 & 人内 \\
\hline & $1.2 \%$ & $0.4 \%$ & $2.4 \%$ & $0.8 \%$ & $5.8 \%$ & $1.8 \%$ & $1.4 \%$ & $0.6 \%$ & $0.2 \%$ & $14 \%$ & $9 \%$ \\
\hline & & 001 & & 05 & $\begin{array}{r}\mathrm{O}] \\
{[1.69}\end{array}$ & .4 & & $\begin{array}{l}\text { 用量 vs A } \\
\text { OR } 7.15\end{array}$ & & & \\
\hline
\end{tabular}

IST: International Stroke Trial, TOAST: Trial of Org 10172 in Acute Stroke Treatment, HAEST: Heparin in Acute Embolic Stroke Trial, TAIST: Tinzaparin in Acute Ischaemic Stroke Trial, FISS-tris: Fraxiparin in Stroke Study in for the treatment of ischemic stroke, ASA: aspirin, UFH: unfractionated heparin, LMWH: low moleculer weight heparin, AF: atrial fibrillation, mRS: modified Rankin Scale, OR: オッズ比

LMWH 群で多い傾向にあったが，3 カ月後時点で 差はなく, 10 日以内の重篤出血が有意に増加した。

Heparin in Acute Embolic Stroke Trial(HAEST) ${ }^{4)}$ は, 発症 30 時間以内の心房細動を有する脳梗塞 449 例 を対象に, LMWH(dalteparin 100 IU/kg 1 日 2 回皮下 注)とアスピリン $(160 \mathrm{mg} /$ 日)の比較が行われた。 14 日以内の脳梗塞再発に差はなく, 症候性頭蓋内出血 の発生にも有意差はなかったが, 頭蓋内出血は LMWH 群で有意に増加した。

Tinzaparin in Acute Ischaemic Stroke Trial (TAIST) ${ }^{5)}$ では, 発症 48 時間以内の急性期脳梗塞 1486 例を, 高用量 LMWH (tinzaparin 175 抗 Xa 因子活性単位), 中用量 LMWH(tinzaparin 100 抗 Xa 因子活性単位) 扮
よびアスピリン (300 mg/日)の 3 群にランダム化し, 6 力月後の転帰を比較した。全体成績で 3 群間に差 はなく, 対象を心原性脳塞栓症に限っても効果はな かった，高用量 LMWH 群は静脈血栓塞栓症がアス ピリン群より有意に少なかった $(0.4 \%$ vs $2.6 \%$ ，オッ ズ比 0.15)が，症候性頭蓋内出血は増加した。

Fraxiparin in Stroke Study for the treatment of ischemic stroke(FISS-tris) 試験6) は，発症 48 時間以内の 急性期脳梗塞 603 例を LMWH 群とアスピリン群に ランダム化し， Nadroparin 皮下注とアスピリンの効 果を比較した試験である。先行した FISS および FISbis 試験から有効性が示唆された，頭蓋内主幹動脈 病変を有する 353 例 (LMWH 群 180 例, アスピリン 
オッズ比 $[95 \% \mathrm{Cl}]$

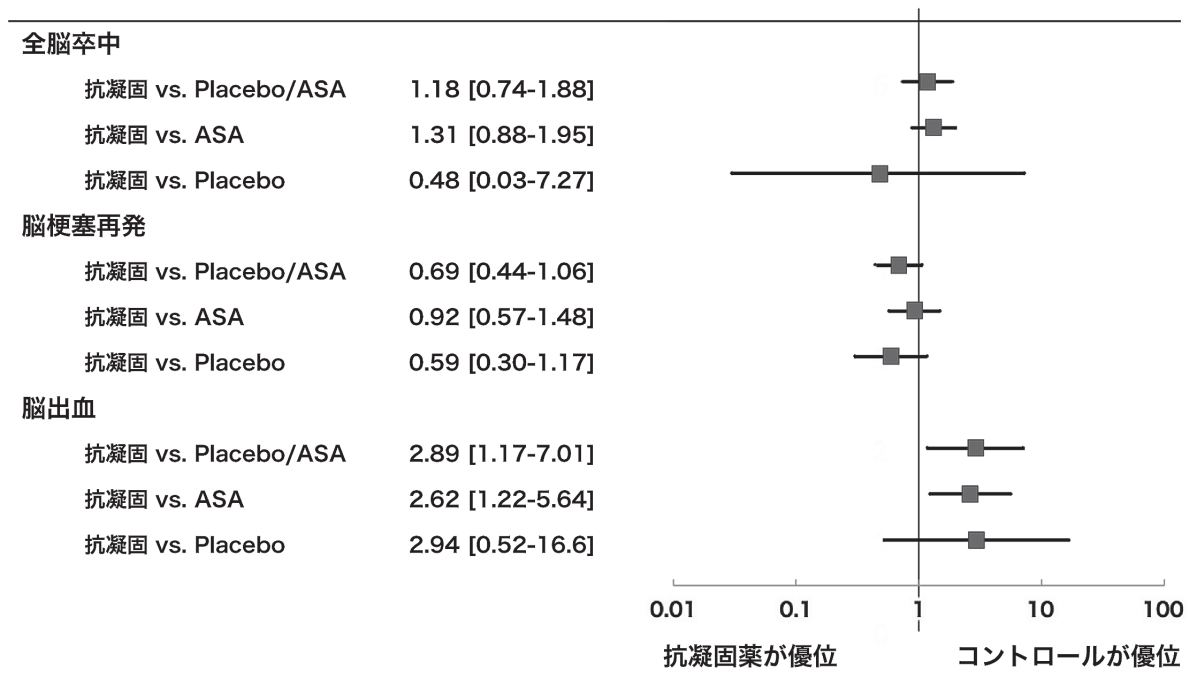

図 2 心原性脳塞栓症急性期における抗凝固療法とイベント発生リスク ASA：アスピリン，（文献 9 より引用作成）

群 173 例)が解析されたが， Nadroparin 皮下注 $(3,800$ 抗 Xa 因子活性単位, 1 日 2 回) はアスピリン (1 日 $160 \mathrm{mg}$ )の効果を上回ることはなかった。しかしサブ 解析では, 高齢者, 抗血小板薬非服用者, 後方循環 系虚血では有効かもしれないと報告されている77.

c. 未分画へパリンと低分子ヘパリンの統合解析

2007 年までに報告されたランダム化比較試験の うち, 脳梗塞発症 14 日以内に抗凝固療法 $(\mathrm{UFH}$, LMWH またはへパリノイド)を用いプラセボとの比 較を行った 24 試験 35,748 例のメ夕解析 ${ }^{8)}$ では, 全 死亡, 要介護の転帰に有意差はなく, 抗凝固群では, 脳梗塞の再発は少なかったが，症候性頭蓋内出血が 増加した。一方, 深部静脈血栓症と肺塞栓症の減少 は有意であったが，この効果は頭蓋外出血の増加に よって打ち消されていた。 さらに，対象を心原性脳 塞栓症に限定して統合解析を行っても, 脳梗塞再発 抑制よりも脳出血増加のリスクのほうが大きいこと が示されている $(\text { 図 2 })^{9)}$.

\section{d. アルガトロバン}

わが国で開発された選択的な合成抗卜ロンビン薬 である。発症 48 時間以内の脳血栓症における神経 学的転帰を改善させ, 出血性合併症が少ないと報告 されている。体で，いわゆるアテローム血栓性脳 梗塞に保険適応となっているが，海外で実施された Argatroban anticoagulation in patients with acute isch- emic stroke (ARGIS-1) 試験では，発症 12 時間以内の 脳梗塞に対するアルガトロバン投与は安全であった ものの有効性はみられなかった ${ }^{10)}$.

注目されているのは急性期血行再建時の併用薬と しての意義である。パイロット研究である Argatroban tPA stroke study (ARTSS) ${ }^{11)}$ で, rt-PA 静注開始後 1 時間以内にアルガトロバンを投与し aPTT を前值の 1.7 倍で 48 時間継続したところ, 症候性頭蓋内出血 を増やすことなく $(4.6 \%)$, 再開通率は $61 \%$ に達した。 この結果を受け Phase $2 b$ 試験 Argatroban in Combination with Recombinant Tissue Plasminogen Activator for Acute Stroke(ARTSS-2) が実施された。tPA 単独, 低用量アルガトロバン併用 (aPTT を前值の 1.75 倍に 管理), 高用量アルガトロバン併用 (aPTT 2.25 倍)の 3 群比較を行っていたが，血栓回収療法のエビデン 又確立を受け，90 例 (目標 105 例) 登録時点で中止 された，最終結果は， mRS 0-1 の割合が tPA 単独で $21 \%$, 低用量アルガトロバン群 30\%, 高用量 32\%, 症候性頭蓋内出血は二用量合わせて $4.9 \%$ (tPA 単独 群は $0 \%)$ という結果であった。現在，血栓回収療法 におけるアルガトロバン併用療法 (ARTSS-IA study, NCT02448069)が実施されている.

\section{2) 内服薬}

心原性脳塞栓症の急性期は再発率が 5〜 14\% と高 く ${ }^{12)}$, この時期に抗凝固療法を行えば再発率の低下 


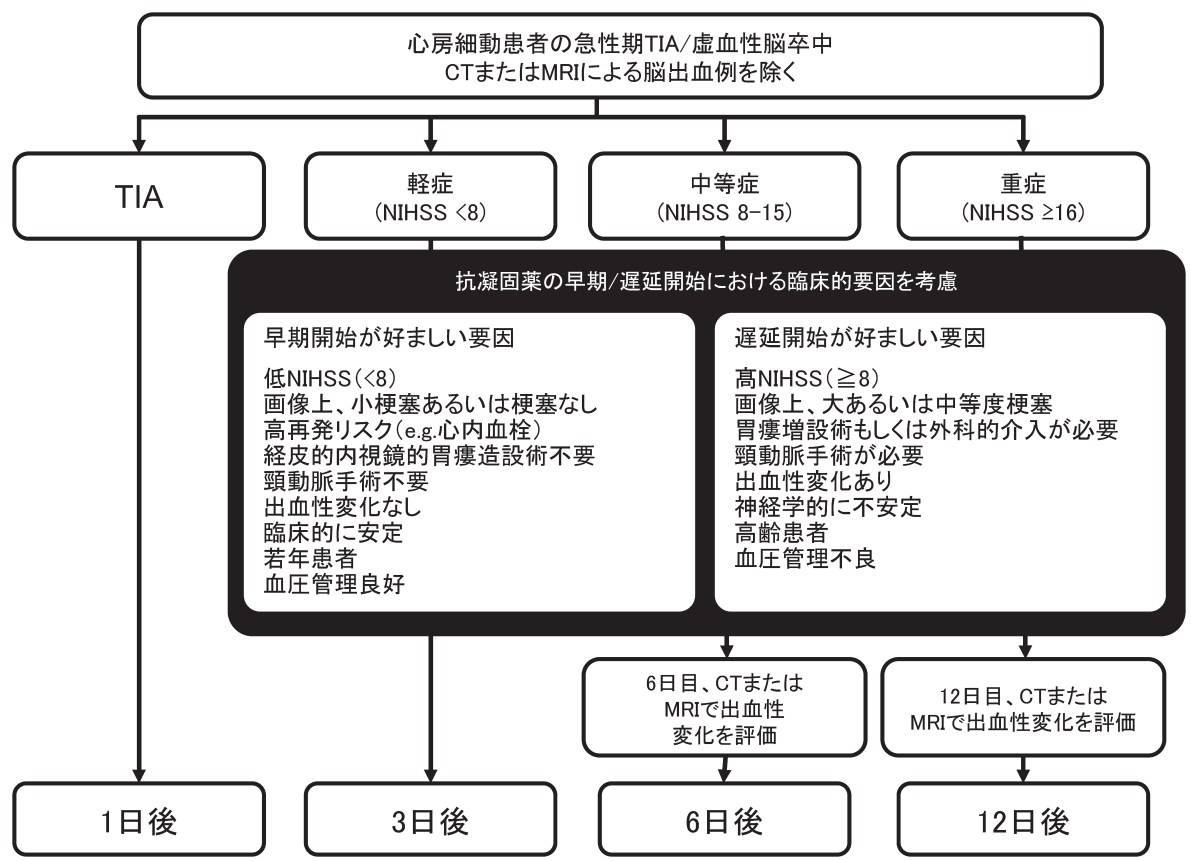

図 3 急性虚血性脳卒中に対する抗凝固療法の開始／再開のフローチャート TIA：一過性脳虚血発作, NIHSS: National Institutes of Health Stroke Scale (文献 14 より引用作成)

が期待できる。一方，栓子融解による閉塞血管の再 開通現象と関連した出血性梗塞もこの時期にみられ ることから, 早期の抗凝固療法導入はかえって病態 を悪化させてしまう懸念もある ${ }^{13)}$ 。急性期の至適開 始時期については，いまだに議論が続いている。日 本の脳卒中治療ガイドライン 2015 は発症から 2 週 間以内を目安とし，大梗塞例や血圧コントロール不 良例，出血傾向のある患者では投与開始を遅らせざ るをえないと記載している。

欧州心臟律動学会 (European Heart Rhythm Association: EHRA) では，以前より 1-3-6-12 Day rule を提 唱しており, 一過性脳虚血発作では 1 日後, 脳梗塞 例では重症度に応じて軽症例 $($ NIHSS $<8) 3$ 日後, 中 等症 (NIHSS 8-15) 6 日後, 重症例 (NIHSS $\geq 16) 14$ 日 後からの抗凝固開始を推奨している ${ }^{14)}$. エキスパー トオピニオンとして提唱され，エビデンスに基づい たものではない，ただし実臨床に役立つ内容となる よう頻回にアップデートされ，最新版では患者個々 の病状に応じてフレキシブルに抗凝固開始時期を調 整できるようなガイドとなっている $(\text { 図 } 3)^{14)}$. a. ワルファリン

もとよりワルファリンは即効性がないため, 急性 期治療には不向きである。また，ワルファリンは効 果が安定するまでに日数を要し, 導入時に半減期が 短いプロテイン $\mathrm{S}$ やプロテイン $\mathrm{C}$ が先に抑制され, かえって脳梗塞を起こすリスクもある。したがって 再発リスクの高い急性期に導入する場合, 即効性の あるへパリンを併用し，プロトロンビン時間国際標 準化比 (prothrombin time- international normalized ratio: PT-INR) が目標治療域に到達するまでの期間を カバーするのが望ましい. ワルファリン治療の目標 が，INR 2.0〜3.0 であれば $4 \mathrm{mg} /$ 日，1.6〜2.6であれ ば $3.0 \mathrm{mg} /$ 日で開始することが多い.

b. DOAC

DOAC は初回内服から十分な抗凝固作用を発揮 するため，初回内服と同時にへパリンは中止してよ い. 軽症例では理論的にヘパリン投与をスキップす ることも良いが，すべての DOACの臨床試験で脳 梗塞発症 2 週間以内の症例は除外されており（表 2) ${ }^{15-20)}$, 有効性と安全性のデー夕は欠如している. イタリアで行われた観察研究 Early Recurrence and 
表 2 DOAC の主な臨床試験の除外期間

\begin{tabular}{ll}
\hline 臨床試験 & 脳卒中発症からの除外期間(発症から) \\
\hline RE-LY 試験(ダビガトランエテキシラート) & 14 日以内 (重症脳梗塞 6 カ月以内 $)$ \\
ROCKET AF 試験(リバーロキサバン) & 14 日以内 $(T I A 3$ 日以内 $)$ \\
J-ROCKET AF 試験(リバーロキサバン) & (重症脳梗塞 $\mathrm{mRS} \geq 4: 3$ カ月以内 $)$ \\
AVERROES 試験(アピキサバン) & 10 日以内 \\
ARISTOTLE 試験(アピキサバン) & 7 日以内 \\
ENGAGE AF 試験(エドキサバン) & 30 日以内(頭蓋内出血の既往も除外) \\
\hline
\end{tabular}

（文献 15-20より引用作成）

Cerebral Bleeding in Patients With Acute Ischemic Stroke and Atrial Fibrillation(RAF)によると，発症 4～14 日 にヘパリンブリッジを介さず経口抗凝固薬単独投与 する方法が, 再発と出血を最も回避できていた ${ }^{21)}$. DOAC 単独での急性期二次予防の可能性を示唆する 結果といえよう。日本では DOAC の至適開始時期 についての多施設共同研究として Recurrent Embolism Lessened by rivaroxaban, an anti-Xa agent of Early Dosing for acute ischemic stroke and transient ischemic attack with atrial fibrillation(RELAXED)が実施され, 2017 年 3 月にその結果が公開される予定である.

\section{4. 脳梗塞慢性期の抗凝固療法}

脳梗塞慢性期の対象疾患は，心原性脳塞栓症，深 部静脈血栓症を伴う脳卒中, 抗リン脂質抗体症候群 に伴う脳梗塞, 脳静脈洞血栓症に伴う脳梗塞などで ある。DOAC は, 非弁膜症性心房細動 (non-valvular atrial fibrillation, NVAF)に伴う脳梗塞あるいは深部 静脈血栓症の合併例には適応があるが，それ以外の 場合はワルファリンによる PT-INR 2.0〜3.0での管 理が推奨される.

\section{1）注射薬}

慢性期治療の原則は，内服療法である。例外的に, 悪性腫瘍を合併した脳梗塞ではへパリン皮下注が選 択される。 Trousseau 症候群は多くの悪性腫瘍にみ られる過凝固状態であるが, 膵癌, 肺癌, 大腸癌, 胃癌, 乳癌などの腺癌と白血病で多い。長期予後は 原疾患によって規定されるが, 治療効果はワルファ リンより低分子ヘパリン $200 \mathrm{IU} / \mathrm{kg}$ の皮下注が勝っ ている22).

\section{2）内服薬}

脳卒中治療ガイドライン 2015 では, NVAFを持 つ脳梗塞または一過性脳虚血発作の再発予防に, 多 ビガトラン, リバーロキサバン, アピキサバン, エ ドキサバン，またはワルファリンによる抗凝固療法 をグレードBで推奨している，ワルファリンは，脳 梗塞再発予防効果で多くのエビデンスを持つが，出 血合併症の頻度が高い. したがって同じ推奨グレー ドであれば，まずDOACを考慮するよう述べている。

a. ワルファリン

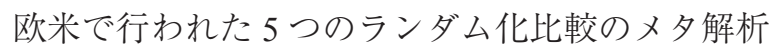
から, NVAFにおけるワルファリン療法は脳梗塞の発 症を $68 \%$ 減じることが明らかにされている，各 RCT におけるINR 目標值は異なるが，ワルファリン内服 中の脳梗塞発症例，あるいは重篤な出血合併症を発 症した例の解析結果から，ワルファリンの至適治療 域は PT-INR 2.0〜3.0 と設定された。体人は，欧米 人に比しワルファリン関連出血リスクが高いため, 70 歳以上の高齢者では PT-INR 1.6〜2.6で管理する.

b. DOAC

すべての DOAC の大規模臨床試験で, 脳卒中二 次予防集団を抽出したサブ解析が行われている（表 $3)^{23-27)}$ 。脳卒中 $/$ 全身塞栓症の発症率は, どの DOAC もワルファリン群と差はない(図 4 ${ }^{23-27)}$ 。 ま た大出血の発症率はワルファリン群と差がない, あ るいはDOAC 群で少ないことが示されている(図 5) $)^{23-27)}$.

$4 つ$ DOAC 臨床試験 (RE-LY, ROCKET AF, ARISTOTLE， ENGAGE AF-TIMI 48)のメ夕解析にお ける脳卒中／TIAの既往の有無別のデータでは，ワ ルファリン群に対して脳卒中／全身塞栓症の発症に ついては「既往なし」では 0.78(95\%信頼区間 0.66〜 


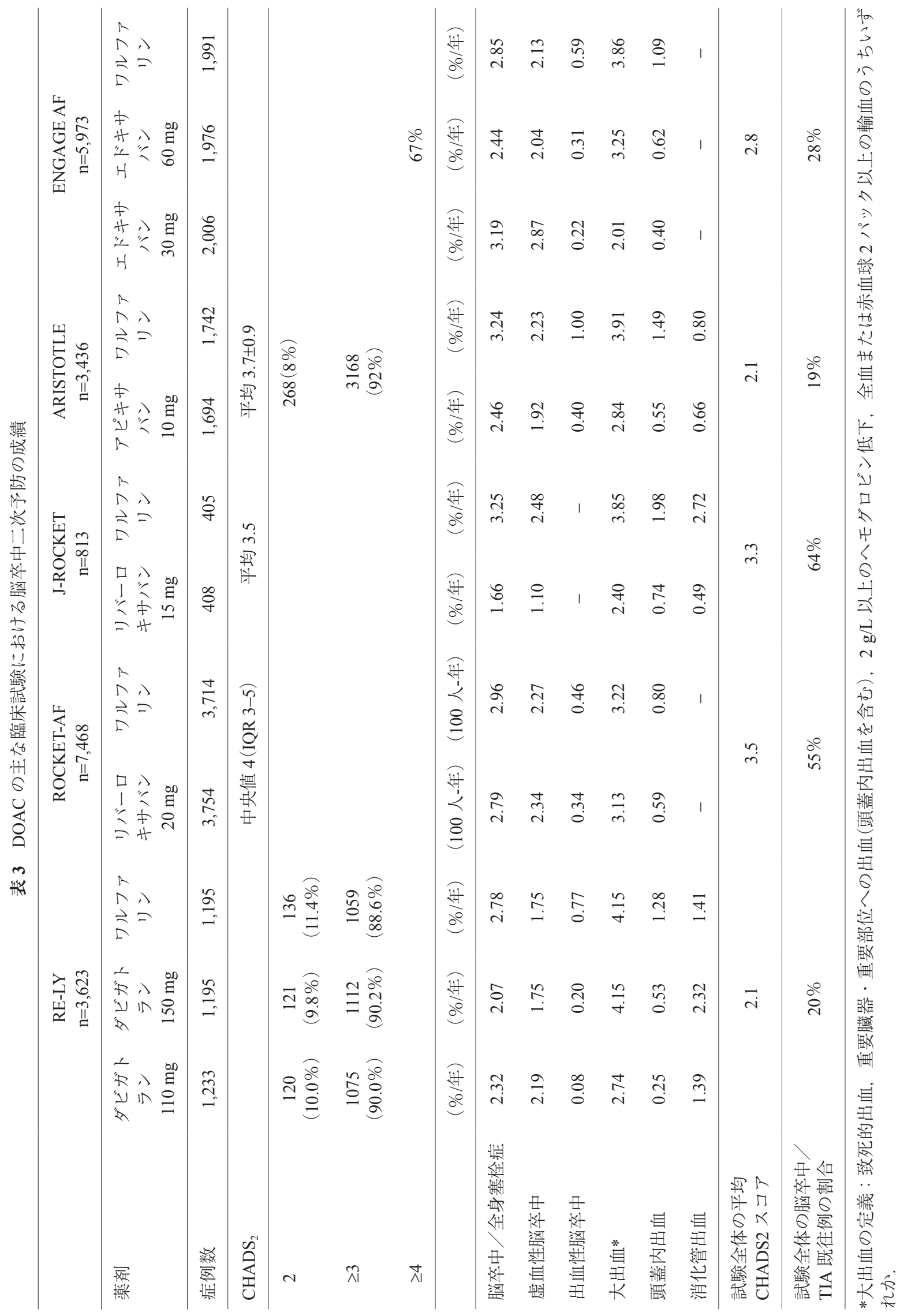


(\%/年) RE-LY ROCKET AF J-ROCKET AF ARISTOTLE ENGAGE AF

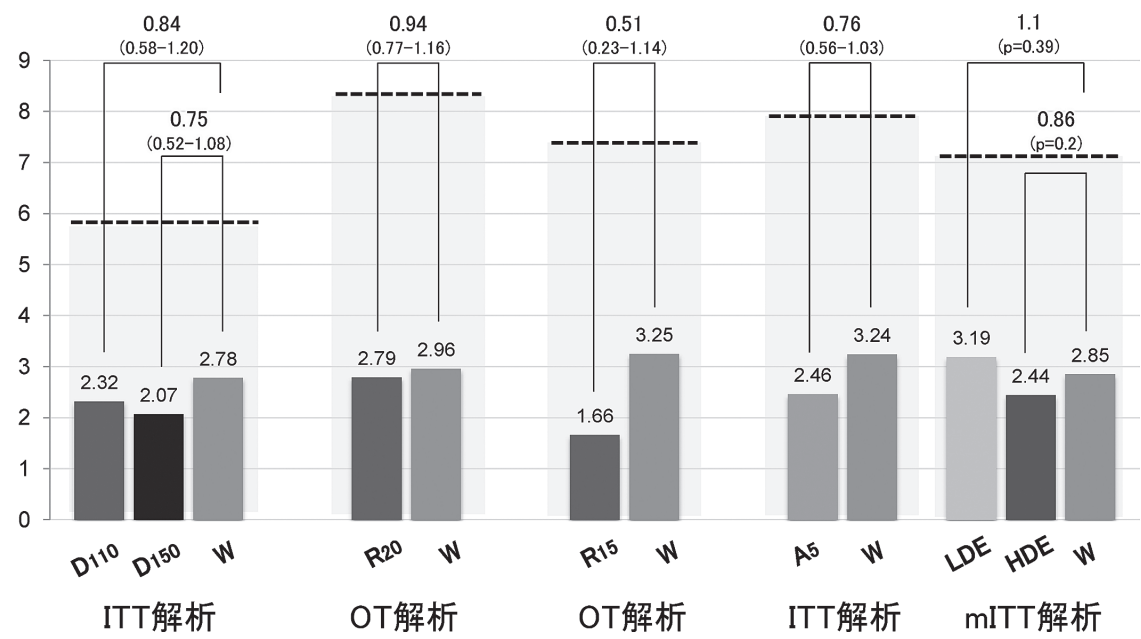

図 4 DOAC 臨床試験における二次予防集団での脳卒中／全身塞栓症発症率 D150：ダビガトラン $150 \mathrm{mg} \times 2$ 服用群, D110：ダビガトラン $110 \mathrm{mg} \times 2$ 服用群, R20： リバーロキサバン $20 \mathrm{mg} \times 1$ 服用群, $\mathrm{R} 15$ ：リバーロキサバン $15 \mathrm{mg} \times 1$ 服用群, A5：ア ピキサバン $5 \mathrm{mg} \times 2$ 服用群, $\mathrm{HDE}$ : エドキサバン $60 / 30 \mathrm{mg} \times 1$ 服用群, LDE：エドキサバン 30/15 mg $\times 1$ 服用群, W : ワルファリン服用群, OT: on treatment, ITT: intention-to-treat （文献 23-27 より引用作成）

$(\% /$ 年 $)$ RE-LY ROCKET AF J-ROCKET AF ARISTOTLE ENGAGE AF

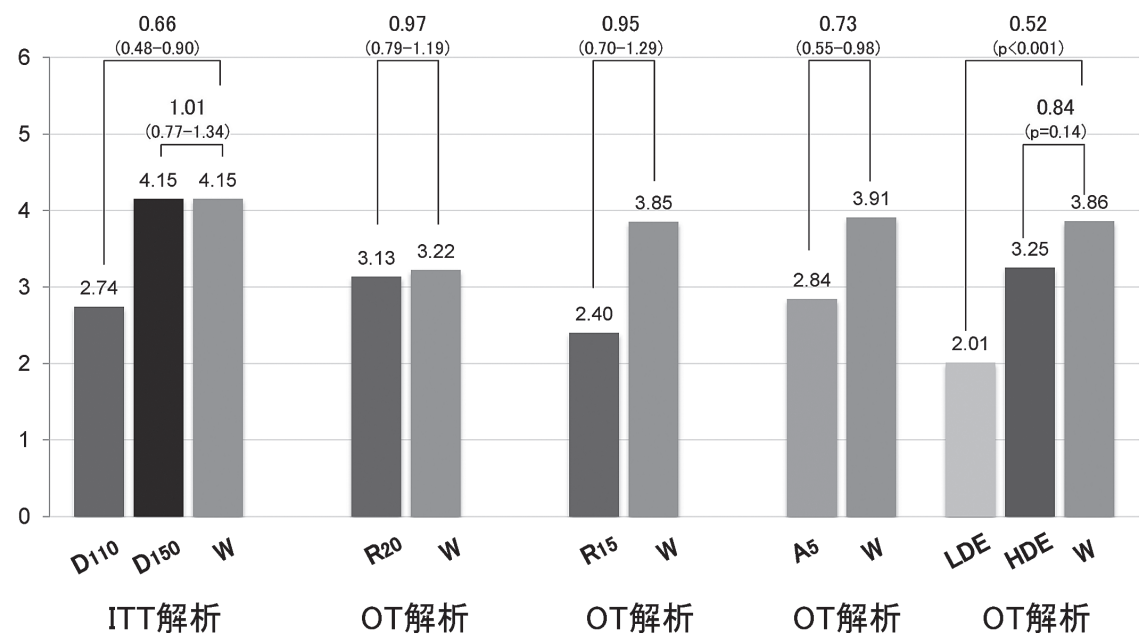

図 5 DOAC 臨床試験における二次予防集団での大出血発症率

D150：ダビガトラン $150 \mathrm{mg} \times 2$ 服用群, D110：ダビガトラン $110 \mathrm{mg} \times 2$ 服用群, R20： リバーロキサバン $20 \mathrm{mg} \times 1$ 服用群, $\mathrm{R} 15$ ：リバーロキサバン $15 \mathrm{mg} \times 1$ 服用群, $\mathrm{A} 5$ ：ア ピキサバン $5 \mathrm{mg} \times 2$ 服用群, $\mathrm{HDE}$ : エドキサバン $60 / 30 \mathrm{mg} \times 1$ 服用群, LDE：エドキサバン 30/15 mg×1 服用群, W : ワルファリン服用群, OT: on treatment, ITT: intention-to-treat (文献 23-27 より引用作成)

0.91)，「既往あり」で $0.86(0.76 \sim 0.98)$ ，大出血の発 症率は「既往なし」では $0.85(0.72 \sim 1.01)$,「既往あり」 では $0.89(0.77 〜 1.02)$ という結果であった ${ }^{28)}$. 二次
予防では一次予防より脳卒中／全身塞栓症の減少率 は少ないが, ワルファリンより有意差を持って脳卒 中／全身塞栓症を減少させる。 大出血は一次予防と 
同じく二次予防でもワルファリンと差がないことが 示されている。したがって，二次予防においても DOAC が有用である.

どの DOACを選択するかは, DOACの禁忌, 慎 重投与，薬物相互作用，減量基準をしっかり抑えた 上で，各 DOACの利点・欠点を考慮して選択する. 基本的には一次予防における選択と同じでよいが, 二次予防では高齢，低腎機能，低体重などの抗凝固 療法では問題となるリスクを持っている症例が多い ことに留意する。

\section{5. まとめ}

脳梗塞の抗凝固療法について，急性期と慢性期に 分けて概説した。抗凝固療法を行えば，必ず出血リ スクは高まる。これは DOAC 時代でも変わらない. 現状では，急性期・慢性期に関わらず，脳梗塞の再 発予防が抗凝固療法の主目的である。

\section{著者の利益相反 $(\mathrm{COI})$ の開示 :}

講演料(日本ベーリンガーインゲルハイム，第一三 共, ファイザー, ブリストルマイヤーズ)

\section{文献}

1) FISHER CM: Cerebrovascular diseases: pathophysiology, diagnosis, and treatment. J Chronic Dis 8: 419-447, 1958.

2) The International Stroke Trial (IST): a randomised trial of aspirin, subcutaneous heparin, both, or neither among 19435 patients with acute ischaemic stroke. International Stroke Trial Collaborative Group. Lancet 349: 1569-1581, 1997.

3) The Publications Committee for the Trial of ORG 10172 in Acute Stroke Treatment (TOAST) Investigators: Low molecular weight heparinoid, ORG 10172 (Danaparoid), and outcome after acute ischemic stroke. A randomized controlled trial. JAMA 279: 1265-1272, 1998.

4) Berge E, Abdelnoor M, Nakstad PH, Sandset PM: Low molecular-weight heparin versus aspirin in patients with acute ischaemic stroke and atrial fibrillation: a double-blind randomised study. HAEST Study Group. Heparin in Acute Embolic Stroke Trial. Lancet 355: 1205-1210, 2000.

5) Bath PM, Lindenstrom E, Boysen G, De Deyn P, Friis P, Leys D, Marttila R, Olsson J, O’Neill D, Orgogozo J, Ringelstein B, van der Sande J, Turpie AG: Tinzaparin in acute ischaemic stroke (TAIST): a randomised aspirin-controlled trial. Lancet 358: 702-710, 2001.

6) Wong KS, Chen C, Ng PW, Tsoi TH, Li HL, Fong WC, Yeung J, Wong CK, Yip KK, Gao H, Wong HB; FISS-tris Study Investigators: Low-molecular-weight heparin compared with aspirin for the treatment of acute ischaemic stroke in Asian patients with large artery occlusive disease: a randomised study. Lancet Neurol 6: 407-413, 2007.

7) Wang QS, Chen C, Chen XY, Han JH, Soo Y, Leung TW, Mok V, Wong KS: Low-molecular-weight heparin versus aspirin for acute ischemic stroke with large artery occlusive disease: subgroup analyses from the Fraxiparin in Stroke Study for the treatment of ischemic stroke (FISS-tris) study. Stroke 43: 346-349, 2012.

8) Sandercock PA, Counsell C, Kamal AK: Anticoagulants for acute ischaemic stroke. Cochrane Database Syst Rev 4 : CD000024, 2008.

9) Paciaroni M, Agnelli G, Micheli S, Caso V: Efficacy and safety of anticoagulant treatment in acute cardioembolic stroke: a meta-analysis of randomized controlled trials. Stroke 38: 423-430, 2007.

10) LaMonte MP, Nash ML, Wang DZ, Woolfenden AR, Schultz J, Hursting MJ, Brown PM; ARGIS-1 Investigators: Argatroban anticoagulation in patients with acute ischemic stroke (ARGIS-1): a randomized, placebo-controlled safety study. Stroke 35: 1677-1682, 2004.

11) Barreto AD, Alexandrov AV, Lyden P, Lee J, Martin-Schild S, Shen L, Wu TC, Sisson A, Pandurengan R, Chen Z, Rahbar MH, Balucani C, Barlinn K, Sugg RM, Garami Z, Tsivgoulis G, Gonzales NR, Savitz SI, Mikulik R, Demchuk AM, Grotta JC: The argatroban and tissue-type plasminogen activator stroke study: final results of a pilot safety study. Stroke $\mathbf{4 3}$ 770-775, 2012.

12) Hart RG, Pearce LA, Aguilar MI: Meta-analysis: antithrombotic therapy to prevent stroke in patients who have nonvalvular atrial fibrillation. Ann Intern Med 146: 857-867, 2007.

13) Furie KL, Kasner SE, Adams RJ, Albers GW, Bush RL, Fagan SC, Halperin JL, Johnston SC, Katzan I, Kernan WN, Mitchell PH, Ovbiagele B, Palesch YY, Sacco RL, Schwamm LH, Wassertheil-Smoller S, Turan TN, Wentworth D; American Heart Association Stroke Council, Council on Cardiovascular Nursing, Council on Clinical Cardiology, and Interdisciplinary Council on Quality of Care and Outcomes Research: Guidelines for the prevention of stroke in patients with stroke or transient ischemic attack: a guideline for healthcare professionals from the american heart association/american stroke association. Stroke 42: 227-276, 2011.

14) Kirchhof $\mathrm{P}$, Benussi S, Kotecha D, Ahlsson A, Atar D, Casadei B, Castella M, Diener HC, Heidbuchel H, Hendriks J, Hindricks G, Manolis AS, Oldgren J, Popescu BA, Schotten U, Van Putte B, Vardas P, Agewall S, Camm J, Baron Esquivias G, Budts W, Carerj S, Casselman F, Coca A, De Caterina R, Deftereos S, Dobrev D, Ferro JM, Filippatos G, Fitzsimons D, Gorenek B, Guenoun M, Hohnloser SH, Kolh P, Lip GY, Manolis A, McMurray J, Ponikowski P, Rosenhek R, Ruschitzka F, Savelieva I, Sharma S, Suwalski P, Tamargo JL, Taylor CJ, Van Gelder IC, Voors AA, Windecker S, Zamorano JL, Zeppenfeld K: 2016 ESC guidelines for the management of atrial fibrillation developed in collaboration with EACTS. Eur Heart J 37: 2893-2962, 2016.

15) Connolly SJ, Ezekowitz MD, Yusuf S, Eikelboom J, Oldgren J, Parekh A, Pogue J, Reilly PA, Themeles E, Varrone J, Wang S, 
Alings M, Xavier D, Zhu J, Diaz R, Lewis BS, Darius H, Diener HC, Joyner CD, Wallentin L; RE-LY Steering Committee and Investigators: Dabigatran versus warfarin in patients with atrial fibrillation. N Engl J Med 361: 1139-1151, 2009.

16) Patel MR, Mahaffey KW, Garg J, Pan G, Singer DE, Hacke W, Breithardt G, Halperin JL, Hankey GJ, Piccini JP, Becker RC, Nessel CC, Paolini JF, Berkowitz SD, Fox KA, Califf RM; ROCKET AF Investigators: Rivaroxaban versus warfarin in nonvalvular atrial fibrillation. N Engl J Med 365: 883-891, 2011.

17) Hori M, Matsumoto M, Tanahashi N, Momomura S, Uchiyama S, Goto S, Izumi T, Koretsune Y, Kajikawa M, Kato M, Ueda $\mathrm{H}$, Iwamoto K, Tajiri M; J-ROCKET AF study investigators: Rivaroxaban vs. warfarin in Japanese patients with atrial fibrillation-the J-ROCKET AF study-. Circ J 76: 2104 2111, 2012.

18) Connolly SJ, Eikelboom J, Joyner C, Diener HC, Hart R, Golitsyn S, Flaker G, Avezum A, Hohnloser SH, Diaz R, Talajic M, Zhu J, Pais P, Budaj A, Parkhomenko A, Jansky P, Commerford P, Tan RS, Sim KH, Lewis BS, Van Mieghem W, Lip GY, Kim JH, Lanas-Zanetti F, Gonzalez-Hermosillo A, Dans AL, Munawar M, O’Donnell M, Lawrence J, Lewis G, Afzal R, Yusuf S; AVERROES Steering Committee and Investigators: Apixaban in patients with atrial fibrillation. $\mathrm{N}$ Engl J Med 364: 806-817, 2011.

19) Granger CB, Alexander JH, McMurray JJ, Lopes RD, Hylek EM, Hanna M, Al-Khalidi HR, Ansell J, Atar D, Avezum A, Bahit MC, Diaz R, Easton JD, Ezekowitz JA, Flaker G, Garcia D, Geraldes M, Gersh BJ, Golitsyn S, Goto S, Hermosillo AG, Hohnloser SH, Horowitz J, Mohan P, Jansky P, Lewis BS, Lopez-Sendon JL, Pais P, Parkhomenko A, Verheugt FW, Zhu J, Wallentin L; ARISTOTLE Committees and Investigators: Apixaban versus warfarin in patients with atrial fibrillation. N Engl J Med 365: 981-992, 2011.

20) Giugliano RP, Ruff CT, Braunwald E, Murphy SA, Wiviott SD, Halperin JL, Waldo AL, Ezekowitz MD, Weitz JI, Špinar J, Ruzyllo W, Ruda M, Koretsune Y, Betcher J, Shi M, Grip LT, Patel SP, Patel I, Hanyok JJ, Mercuri M, Antman EM; ENGAGE AF-TIMI 48 Investigators: Edoxaban versus warfarin in patients with atrial fibrillation. N Engl J Med 369: 2093-2104, 2013.

21) Paciaroni M, Agnelli G, Falocci N, Caso V, Becattini C, Marcheselli S, Rueckert C, Pezzini A, Poli L, Padovani A, Csiba L, Szabó L, Sohn SI, Tassinari T, Abdul-Rahim AH, Michel P, Cordier M, Vanacker P, Remillard S, Alberti A, Venti M, Scoditti U, Denti L, Orlandi G, Chiti A, Gialdini G, Bovi P, Carletti M, Rigatelli A, Putaala J, Tatlisumak T, Masotti L, Lorenzini G, Tassi R, Guideri F, Martini G, Tsivgoulis G, Vadikolias K, Liantinioti C, Corea F, Del Sette M, Ageno W, De Lodovici ML, Bono G, Baldi A, D’Anna S, Sacco S, Carolei A, Tiseo C, Acciarresi M, D'Amore C, Imberti D, Zabzuni D, Doronin B, Volodina V, Consoli D, Galati F, Pieroni A, Toni D, Monaco S, Baronello MM, Barlinn K, Pallesen LP, Kepplinger J, Bodechtel U, Gerber J, Deleu D, Melikyan G, Ibrahim F, Akhtar N, Mosconi MG, Bubba V, Silvestri I, Lees KR: Early Recurrence and Cerebral Bleeding in Patients With Acute Ischemic Stroke and Atrial Fibrillation: Effect of Anticoagulation and Its Timing: The RAF Study. Stroke 46: 2175-2182, 2015.

22) Lee AY, Levine MN, Baker RI, Bowden C, Kakkar AK, Prins M, Rickles FR, Julian JA, Haley S, Kovacs MJ, Gent M; Randomized Comparison of Low-Molecular-Weight Heparin versus Oral Anticoagulant Therapy for the Prevention of Recurrent Venous Thromboembolism in Patients with Cancer (CLOT) Investigators: Low-molecular-weight heparin versus a coumarin for the prevention of recurrent venous thromboembolism in patients with cancer. N Engl J Med 349: 146153, 2003.

23) Diener HC, Connolly SJ, Ezekowitz MD, Wallentin L, Reilly PA, Yang S, Xavier D, Di Pasquale G, Yusuf S; RE-LY study group: Dabigatran compared with warfarin in patients with atrial fibrillation and previous transient ischaemic attack or stroke: a subgroup analysis of the RE-LY trial. Lancet Neurol 9: 1157-1163, 2010.

24) Hankey GJ, Patel MR, Stevens SR, Becker RC, Breithardt G, Carolei A, Diener HC, Donnan GA, Halperin JL, Mahaffey KW, Mas JL, Massaro A, Norrving B, Nessel CC, Paolini JF, Roine RO, Singer DE, Wong L, Califf RM, Fox KA, Hacke W; ROCKET AF Steering Committee Investigators: Rivaroxaban compared with warfarin in patients with atrial fibrillation and previous stroke or transient ischaemic attack: a subgroup analysis of ROCKET AF. Lancet Neurol 11: 315-322, 2012.

25) Tanahashi N, Hori M, Matsumoto M, Momomura S, Uchiyama S, Goto S, Izumi T, Koretsune Y, Kajikawa M, Kato M, Ueda H, Iwamoto K, Tajiri M; J-ROCKET AF Study Investigators: Rivaroxaban versus warfarin in Japanese patients with nonvalvular atrial fibrillation for the secondary prevention of stroke: a subgroup analysis of J-ROCKET AF. J Stroke Cerebrovasc Dis 22: 1317-1325, 2013.

26) Easton JD, Lopes RD, Bahit MC, Wojdyla DM, Granger CB, Wallentin L, Alings M, Goto S, Lewis BS, Rosenquist M, Hanna M, Mohan P, Alexander JH, Diener HC; ARISTOTLE Committees and Investigators: Apixaban compared with warfarin in patients with atrial fibrillation and previous stroke or transient ischaemic attack: a subgroup analysis of the ARISTOTLE trial. Lancet Neurol 11: 503-511, 2012.

27) Rost NS, Giugliano RP, Ruff CT, Murphy SA, Crompton AE, Norden AD, Silverman S, Singhal AB, Nicolau JC, SomaRaju B, Mercuri MF, Antman EM, Braunwald E; ENGAGE AFTIMI 48 Investigators: Outcomes With Edoxaban Versus Warfarin in Patients With Previous Cerebrovascular Events: Findings From ENGAGE AF-TIMI 48 (Effective Anticoagulation With Factor Xa Next Generation in Atrial Fibrillation-Thrombolysis in Myocardial Infarction 48). Stroke 47: 2075-2082, 2016.

28) Ruff CT, Giugliano RP, Braunwald E, Hoffman EB, Deenadayalu N, Ezekowitz MD, Camm AJ, Weitz JI, Lewis BS, Parkhomenko A, Yamashita T, Antman EM: Comparison of the efficacy and safety of new oral anticoagulants with warfarin in patients with atrial fibrillation: a meta-analysis of randomised trials. Lancet 383: 955-962, 2014. 